\title{
FACTORY LEGISLATION FOR WOMEN IN CANADA.
}

BEFORE entering upon the subject proper, it seems necessary to make some comments upon the manufacturing interests of the country under consideration. A mere presentation of the protective laws would seem to place Canada in a bad light when compared with Great Britain and the United States. But, when read with an intelligent understanding of her position among the manufacturing nations of the world, odious comparisons cannot be drawn.

Although Canada is not primarily a manufacturing country, yet the manufactures of certain portions are worthy of attention. Like other new countries, ${ }^{,}$the vast agricultural interests are the most prominent. Canada, as a united colony, is new, the first of last July marking the thirty-second year of her birth. And this is but a short time in which to develop industries. The great part of the Dominion yet in its infancy may have before it a future in which untold wealth shall be gained from its manufactures. The mighty prairies of the Northwest may yet have great manufacturing centers. The Klondike gold may build great cities on the western wilds. But all this is suppositious. What exists now is the vital question.

The smaller and the older Canada, too, looks chiefly to agriculture, mining, and fishing for its revenue, but manufacturing is receiving some share of attention, particularly in Quebec and Ontario. In the maritime provinces it is not of the same importance. Canning factories for the preserving of fish and fruit, and cotton and woolen factories, and sugar refineries, are the most prominent.

With such a condition of affairs, it is not surprising that factory legislation should not have attained the proportions that it has in England and the United States. In both of these countries we have nearly a half century of struggle before any legal attempts were made to lessen the evils connected with factory life.

INo attempt has been made to include an account of the manufactures of the separate colonies prior to the formation of the confederation in 1867 . 
The shocking brutalities practiced upon the employés in British factories in the early part of this century have no parallel in Canadian history. The factories here have grown up gradually, and at no time has there been a literal emptying of the country into manufacturing towns, as was the case in New England forty or fifty years ago. Manufacturing industries in Canada are on the increase, as is seen by examination of the censuses of the last three decades. Small industries are continually springing up, and the number of large ones has greatly increased. The actual increase for the Dominion for the last twenty years is as follows :

\begin{tabular}{|c|c|c|c|}
\hline Year & $\begin{array}{c}\text { Number of } \\
\text { establishments }\end{array}$ & $\begin{array}{l}\text { Value of articles } \\
\text { produced }\end{array}$ & Number employés \\
\hline I $871 \ldots \ldots \ldots$ & & $\$ 221,6$ I 7,773 & I 87,942 \\
\hline І $88 \mathrm{r} \ldots \ldots \ldots \ldots \ldots \ldots \ldots \ldots \ldots \ldots \ldots \ldots \ldots$ & $49,73 \mathrm{I}$ & $309,731,867$ & 254,894 \\
\hline I $891 . \ldots \ldots$ & 75,968 & $476,258,886$ & 370,256 \\
\hline
\end{tabular}

The census of I87 I does not give the number of establishments, and the figures for that year are for only the four original provinces. Since confederation there has been a steady growth of factories. The growth has been rapid, too, when we consider the population of the country and its increase during the same period, which is as follows :

\begin{tabular}{|c|c|c|c|c|c|c|}
\hline Year & & & & & & Pop \\
\hline I 87 I & & & - & & - & \\
\hline & & - & & - & & \\
\hline & & & - & & & $4,833,23$ \\
\hline
\end{tabular}

The increase in the twenty years has been about 25 per cent. $(.24+)$. The increase in the number of factory operatives for the same time is just double $(.49+)$; an increase certainly well worthy of attention; and when we consider that a large proportion of these operatives are women, the importance of studying protective legislation becomes evident. There were in $189 \mathrm{I}$-and the numbers have not since decreased-75,968 industrial establishments, employing 370,256 workers; of these 70,280 were 
women and 7,076 girls under sixteen years of age. The tabulated statement below shows how this number is distributed through the various provinces:

\begin{tabular}{|c|c|c|c|c|c|}
\hline \multirow{2}{*}{ Province } & \multirow{2}{*}{$\begin{array}{c}\text { Number of } \\
\text { establishments }\end{array}$} & \multicolumn{4}{|c|}{ Employés } \\
\hline & & Women & Girls & Men & Boys \\
\hline 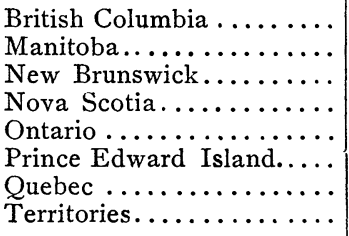 & $\begin{array}{r}770 \\
1,031 \\
5,429 \\
10,496 \\
32,151 \\
2,679 \\
23,037 \\
375\end{array}$ & $\begin{array}{r}\mathrm{I}, 33 \mathrm{I} \\
54 \mathrm{I} \\
4,750 \\
6,566 \\
32,835 \\
\mathrm{I}, 309 \\
22,898 \\
50\end{array}$ & $\begin{array}{r}157 \\
31 \\
568 \\
625 \\
2,482 \\
192 \\
3,018 \\
3\end{array}$ & $\begin{array}{r}9,615 \\
3,279 \\
19,513 \\
25,734 \\
123,527 \\
5,766 \\
84,936 \\
994\end{array}$ & $\begin{array}{r}404 \\
102 \\
\mathrm{I}, 844 \\
2,040 \\
7,872 \\
643 \\
6,537 \\
34\end{array}$ \\
\hline 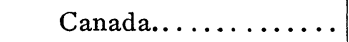 & 75,968 & 70,280 & 7,076 & 273,424 & 19,476 \\
\hline
\end{tabular}

NotE.-Boys and girls are youths from fourteen to sixteen years of age; men and women all over that age.

This table shows that about one-quarter of the employés in the whole country are women and girls, and it is the legislation for this large and important class, numbering 77,356, that we shall now proceed to examine. We may first take up the four original provinces, beginning at the east and with the oldest one.

The story of protective legislation in Nova Scotia is soon told. There is none. But this does not necessarily imply a sluggish state of public morals; it is the result of a comparatively small manufacturing industry, with a correspondingly small call for female labor. Yet, surely, 7, Ig I women and girls are worth governmental care. The number in itself is small, but when we remember that each one represents a present or a future home, it grows in importance.

In the province the ten-hour day, or sixty hours per week, is the rule generally adhered to by employers; but the fixing of time rests wholly with them. No gross abuse of this power appears, and troubles between employer and employed have rarely occurred. The factories are not large, and are located in small towns where public sentiment would not permit the imposition of inhuman tasks. 
Adjoining Nova Scotia, and prior to 1774 a part of it, is the province of New Brunswick, which we shall next consider.

Here we find conditions similar to those in the peninsula. Lumbering and agriculture claim the largest share of the people's attention, and the manufactures do not furnish any very considerable part of the provincial revenue. We find here only 5,318 women workers, and they, as their sisters in Nova Scotia, are dependent upon the leniency of their employers for fair treatment. There are no factory laws, only the penal code to prevent brutal acts.

Next we pass to Quebec with its 25,916 female operatives, and here we find a very good code of factory laws, with special provisions for women and children; and we have two women inspectors whose duty lies wholly among the women employés. They have the rather imposing title of "inspectresses of industrial establishments."

The following is a summary of the laws, taken up under three heads : ${ }^{x}$, inspection provided; II, hours of labor; and III, sanitary regulations.

\section{INSPECTION PROVIDED.}

This was provided in 1889 , and inspectors are appointed by the lieutenant-governor in council. ( 52 Vict., chap. 30.)

\section{HOURS OF LABOR.}

I. No girl or woman shall be employed in any manufacturing establishment or workshop for more than ten hours in any one day or for more than sixty hours in any one week, unless it be for the sole purpose of making a shorter working day on Saturday.

2. One hour shall be allowed each day for meals, if the inspector so direct, but such hour shall not be counted as a part of the working time.

3. The day of ten hours shall not begin before 6 A. M., nor continue after 9 P. M.

I This is the method of treatment adopted by the writer in an article on "Factory Legislation for Women in the United States," American Journal of Sociology, September, I897. 
4. The inspector may, if he sees fit, prolong the employment of children, girls, and women [to twelve hours per day], providing the working day does not begin before 6 A. M., nor continue atter 9 P. M., under the following circumstances:

(a) When any accident, which prevents the working of any industrial establishment, happens to the motive power or machinery.

(b) When, from any occurrence beyond the control of the employer, the machinery, or any part of the machinery, of any industrial establishment cannot be properly worked.

(c) When any stoppage occurs from any cause whatsoever.

5. Employers must keep a register showing the period of each day and week that children, boys, girls, and women are employed, and the hour at which they commenced and finished working.

The text of the foregoing may be found in 57 Vict., chap. 30 , secs. 3025,3026 , and 3027 .

\section{SANITARY REGULATIONS.}

These are not enactments made especially for women, but for all employés, regardless of age or sex. However, it seems fitting to cite them here to show that the health of the women operatives is not neglected.

I. Industrial establishments must be built and kept in such manner as to secure the safety of all employed in them.

2. They must be $(a)$ kept in the cleanest possible manner; (b) sufficiently lighted; (c) have a sufficient quantity of air for the number of persons employed; and $(d)$ provided with effective means for expelling the dust produced during the course of work, and also the gases and vapors which escape and the refuse which results from it. (57 Vict., chap. 30, sec. 3021.)

3. The lieutenant-governor in council may classify as dangerous, unhealthy, or incommodious such establishments as he considers dangerous to the health of the operators, especially children, young girls, and women. (Same as above, sec. 3053.)

The following sanitary measures were approved by the governor in 1895 :

(a) All apartments must be well aired. 
(b) Thermometers shall be kept at spots indicated by the inspector.

(c) Meals must not be eaten in workrooms.

(d) Employers must provide a place where workmen can warm their food and in bad weather eat their meals sheltered from cold, rain, or snow.

(e) Good water and facilities for securing individual cleanliness must be provided.

$(f)$ Suitable and separate closets for the sexes must be furnished.

$(g)$ Women and children must be forbidden to do any operation connected with belting or other modes of transmission.

Besides the above there are a great many measures for the protection of the workmen from machinery, fire, and other dangers, but it is not necessary to enumerate them here. A sufficient number have been specified to show that the sanitary regulations of Quebec are very complete, and, if fearlessly enforced, should render the factory laborer practically safe as far as life and limb are concerned. But accidents do occur, and a great many of them, as seen from the inspector's report. In I 897 we find reported 254 accidents, 24 of which were fatal. Out of the whole number injured only 13 are reported as being women, and none of these died. This is probably owing to the kind of work in which they are engaged. One hundred and fifteen accidents, ten of which were fatal, were due directly to explosions, mainly of boilers, and women are not employed in work which would expose them to such danger.

The latest reports of the inspectors are of a roseate hue, and, if not too highly colored, prove that factory administration in Quebec is of a high order.

As far as women are concerned, the protective legislation compares very favorably with the best that is found in the United States. For here we find only five states regulating the hours of labor of adult women, i.e., women over twenty-one, while thirty-two recognize the importance of fixing a time limit for all under eighteen, or for "children and young girls," in the 
language of the Quebec law. The sanitary regulations are in advance of any others found on the American continent.

Taking up the laws of Ontario in the same manner we have:

\section{INSPECTION PROVIDED.}

This was provided in 1885 (47 Vict., chap. 39), and provision is made for the appointment of a woman inspector at the discretion of the lieutenant-governor in council.

II. HOURS OF LABOR.

I. Ten hours per day, or sixty hours per week, shall be the legal period of work.

2. The hours per day may be differently apportioned for the sole purpose of making a shorter day's work on Saturday.

3. Employers shall allow each child and young girl and woman not less than one hour for meals, but such time must not be considered a part of the ten hours.

4. The inspector may permit overtime where accident, occurrence, custom of, or exigency of trade demands it; provided no young girl or woman shall be employed before 6 A. M., nor after 9 P. M., excepting in factories for canning or desiccating fruit, where the time may be extended, under certain limitations, during the months of July, August, September, and October.

5. That the hours shall not be more than twelve and a half in any one day, nor seventy-two and a half in any one week, and that such exemption shall not comprise more than six weeks in any one year, and that, in addition to the hour allowed at noon, an extra three-quarters be given between the hours of 5 and 8 , when work continues until after 7 P. M.

6. Notice of hours of labor must be posted where women and girls are employed.

7. Employers must keep a register showing exact duration of overtime, if any.

\section{SANITARY REGULATIONS.}

I. Every factory shall be kept in a cleanly state and free from effluvia arising from any source whatever.

2. Factories must not be overcrowded. 
3. Proper ventilation must be provided.

4. Suitable and separate closets and other conveniences must be provided for the sexes.

The text of the foregoing may be found in the Ontario Factories' Act, secs. 6, 7, 8, I0, I I, and 28. (47 Vict., chap. 39, as amended by 50 Vict., chap. 35 ; 52 Vict., chap. 43 ; and 58 Vict., chap. 50. )

We also find general measures for protection against fire and dangerous machinery. In the inspector's report for 1896 there are 174 accidents reported, only seven of them being to women. Here, as in Quebec, this is owing to the kind of work in which women engage.

In Ontario laundries, bakeshops, and stores come under inspection, the last two by separate acts. This is certainly indicative of great progress in Ontario, as it gives us the most extensive legislation of the kind in America. But the force of inspectors is wholly inadequate. There are four inspectors for 32, I5I establishments, with 266,716 workers, and only one woman to look after the interests of 35,317 women operatives.

In the western country the necessity for legislation has not been sufficient to attract attention.

From the above it would appear that a study of factory legislation for women in Canada simplifies itself into a study of the laws of Quebec and Ontario.

Summing up, we have the following table:

\begin{tabular}{|c|c|c|c|c|}
\hline Provinces & $\begin{array}{l}\text { Number of } \\
\text { female } \\
\text { operatives }\end{array}$ & $\begin{array}{l}\text { Number of } \\
\text { inspectors }\end{array}$ & $\begin{array}{l}\text { Number of } \\
\text { women } \\
\text { inspectors }\end{array}$ & $\begin{array}{l}\text { Number of } \\
\text { operatives to } \\
\text { one woman } \\
\text { inspector }\end{array}$ \\
\hline 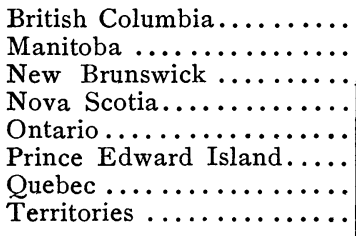 & $\begin{array}{r}\mathrm{I}, 488 \\
57 \mathrm{I} \\
5,3 \mathrm{I} 8 \\
7,19 \mathrm{I} \\
35,3 \mathrm{I} 7 \\
\mathrm{I}, 40 \mathrm{I} \\
25,9 \mathrm{I} 6 \\
53\end{array}$ & $\begin{array}{l}\cdots \\
\cdots \\
\ddot{4} \\
\ddot{4} \\
\ddot{8} \\
\cdots\end{array}$ & $\begin{array}{l}\cdots \\
\cdots \\
\cdots \\
\dot{I} \\
\ddot{2} \\
\cdots\end{array}$ & $\begin{array}{c}\cdots \cdots \\
\cdots \cdots \\
\cdots \cdots \\
\cdots \cdots \\
35,317 \\
\cdots \cdots \\
12,958 \\
\cdots \cdots\end{array}$ \\
\hline
\end{tabular}

Should we be satisfied with this condition? The number of women workers is steadily increasing, and we have reason to believe that it will continue to increase. The provinces should 
be awake to the fact that it is easier to prevent abuses than to rectify them; easier to protect strong women than to care for wrecked ones; easier to guard the mothers of the next generation than to provide homes for deformed and imbecile children a few years hence.

Where the evils connected with female labor are not great, it seems to the provinces a needless expense to provide for factory inspection. Expenses could be limited by placing the work in the hands of local authorities, who could report to a central office. But the appointment of inspectors is not enough. There must be women inspectors where there are women employés. The greatest trials and hardships of a factory woman's life can be told only to one of her own sex. Everywhere the importance - the necessity - of women inspectors should be insisted upon. This is being recognized by all thinking people. The leading women in Canada discussed the matter at a meeting of the National Council several years ago, and on their records stands the following resolution: "That the National Council do recommend all local councils to unite in a petition for the appointment of women inspectors for factories and workshops." And their appointment is looked upon with favor by men. In his report for 1896 the president of the Board of Inspectors of Industrial Establishments for Quebec, in commenting upon the appointment of the two women inspectors in his province, says: "We have but to congratulate the government on this experiment, by which it manifests all the interest it takes in the wives and daughters of workingmen, and the protection it wishes to give them."

It is to be hoped that at no distant date all the provinces of Canada will take steps to regulate the employment of women in the factories. All operatives would thereby be the gainers. Improved conditions for women mean a like improvement for men. No country at any time has attempted to regulate the labor of adult men in factories, as protective legislation has always centered around the weaker classes - the women and the children - but in every case the men have gained by these class enactments. The strength of a nation lies in its workers, 
and whatever is conducive to their good should be regarded as a necessity.

But Canada's watchword is progress, and we may feel sure that she will not be slow to recognize the importance of protecting her women workers from the inevitable evils arising from the rapid growth of manufactures. The time has passed when women depended upon their frailties for protection, but a new and better era is at hand when the working-woman may demand fair treatment in behalf of her womanhood and humanity.

Annie Marion MacLean.

The University of Chicago. 